\title{
The Importance of Food in Tikuna \& Baniwa Culture: Differences and Similarities About Two Brazilian Native Ethnic Groups
}

\author{
Ercila Pinto Monteiro
}

Doctor Student in the Postgraduate Program in Education for Science, UNESP Bauru City, São Paulo (Brazil); Federal University of Amazonas (Brazil)/ Department of Chemistry; monteiro@ufam.edu.br

\section{Diogo Gonzaga Torres Neto}

Doctor Student in the Postgraduate Program in Society and Culture in Amazonia - PPGSCA - UFAM, Manaus, Amazonas (Brazil); Federal University of Rondônia (Brazil)/Department of Administration; diogo@unir.br

\section{Doi:10.5901/mjss.2015.v6n5s1p309}

\section{Abstract}

\begin{abstract}
This article presents the general aspects of the foods of Tikuna and Baniwa ethnic groups, who are indigenous peoples of the Amazonia, whose daily practice of food preparation reflects aspects of indigenous culture, which are strongly influenced by rituals, myths, by meanings and commensality within the small villages tribes. The indigenous peoples food was always filled by the cultivation a lot of plant species and prepared by the field manipulation techniques, cooking, extraction and fermentation, as has been part of indigenous knowledge from Amazonia. Different from western values, the food for the indigenous peoples is loaded with symbolism, commensality and beliefs. The food for the peoples Tikuna has importance given expression and the establishment of social relations between individuals in the villages, while that for the Baniwa food represents beyond the social relation, sacred element or cursed, loaded with symbolism cosmological, which extols their deep relationship with the mythological beliefs. Whereas in recent years the industrialized food also became part of indigenous foods, this paper was important to discuss the nutritional influence has affected the health of indigenous of Tikuna and Baniwa as result of the switching of food habits.
\end{abstract}

Keywords: Food, Ethnic group, Baniwa, Tikuna

\section{Introduction}

Since the times of hunting and gathering, the history of man is related to the practice of eating the food as characteristic of Homo sapiens to ensure their survival. The field of fire for more than 300,000 years, allowed the emergence of the "kitchen", as the first lab of the man, and the preparation of various foods, which have been served from raw to cooked.

The change in food tasting by different preparations in human food has helped to maintain the biological species and introduce new forms of social relations (MOREIRA, 2010). For example, the flesh of fresh game, the fermented beverage, salt and olive oil have become characteristics of the festivals and the relations of coexistence and symbols of friendship. The modification of food from raw to cooked was interpreted by Levi-Strauss as the process of transition from man of biological condition for social, opening up space for the practice of sharing food, called commensality. Therefore, today eat and drink together means the strengthening of friendship, in addition to other meanings.

For some indigenous peoples, the representation will in addition to the friendships, can represent the remembrance of agreements signed and the strengthening of relations to abolish differences between kin. Socially, the food and the different forms of preparation were marked by expression of indigenous identity, based on the knowledge of animal and plant species edible in its surroundings. Particularly the world didn't know the real contribution that the indigenous communities of the Amazon had for production and maintenance of food. Historically, at the time of European conquest were trademarked terms 138 domesticates in the Amazon by indigenous peoples, among them are: the pineapple, cacao (cocoa), manioc and pepper (PEÑA VENEGAS and BERNAL ZAMUDIO, 2011).

The manioc was domesticated for the first time in the world by indigenous peoples of the Amazon region around 8,000 years ago, and is distributed to the tropics, reaching several countries and becoming the sixth cultivation more important in the world. In Brazil, the cacao ( was also tamed for the first time in the Amazon by the natives indians and was soon transferred to the Pará going to Bahia, where he had good adaptation and investment for export of the 
product until ours days. In addition to these crops, the indigenous domesticated pejibaye on Amazon other species at the regional level, such as: the pupunha, guarana, the inga and cupuassu. Unfortunately, this scenario of domestication and sustainability food no longer exists, due to the strong influence of western culture and its process of globalization food. This means that indigenous peoples of the Amazon gave a scenario of planting and harvesting that was interfered with by European presence. Many of the habits and practices were abandoned and remains in a tribe. Currently, indigenous people have introduced into their diet industrialized products, planting fruit and vegetables edible for sell in large centers, in order to buy industrialized food sold on the market. This situation is not different from what can be seen in reality of ethnic groups Ticuna and Baniwa, in spite of being located in the Region of Alto Solimões (Ticuna) and the other in the Region of Alto Rio Negro (Baniwa).

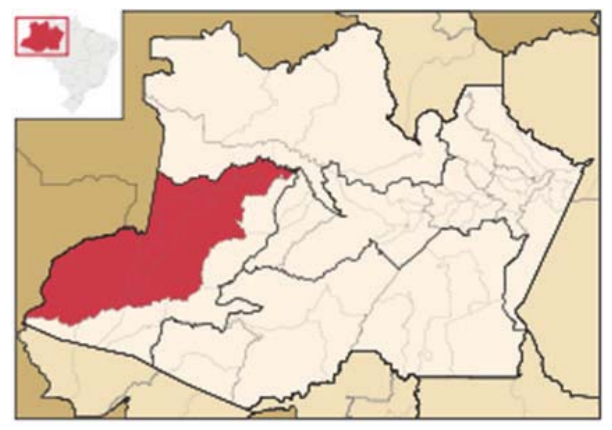

Picture 1A. Region of Alto Solimões (in red), Baniwa Ethnic Group. Image by Raphael Lorenzeto, Gnu Free documentation License, 2006.

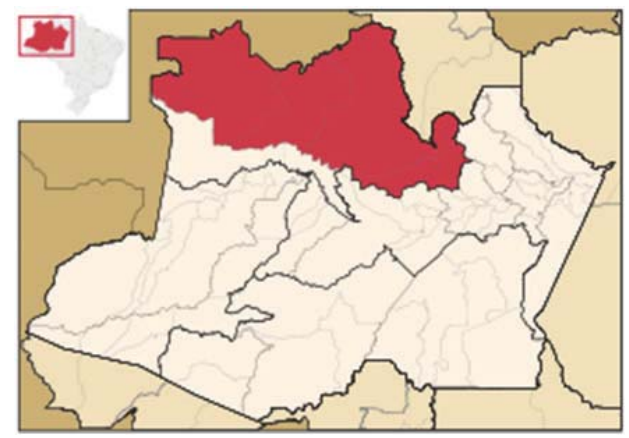

Picture 1B. Region of Alto Rio Negro (in red), Tikuna Ethnic Group. Image by Raphael Lorenzeto, Gnu Free documentation License, 2006.

This article aims to compare the importance of food by mythical vision for the Natives Ethnicities Baniwa and Tikuna. The methods used were the bibliographic research, personal observation and critical hermeneutics. The research was kind of phenomenological and Scientific literature.

\section{The Caractheristics of the Baniwa Culture}

The Baniwa are speakers of a language classified in the Aruak linguistic family and totaling around 4,000 people, distributed in approximately 78 tribes, many of them of difficult access, in the region of Alto Rio Negro, on the border of Brazil and Colombia and Venezuela (CANEIRO et al, 2008). The Baniwa people presents settlements distributed along of the Içana and Aiary rivers, which are tributaries of the Rio Negro river. The kinship is structured through the meeting of kin in three named phratries (Walipere, Hohodene and Dzáwinai), speakers of the same language, that maintains between ceremonial and affinity by relationship (Garnelo, 2007). 


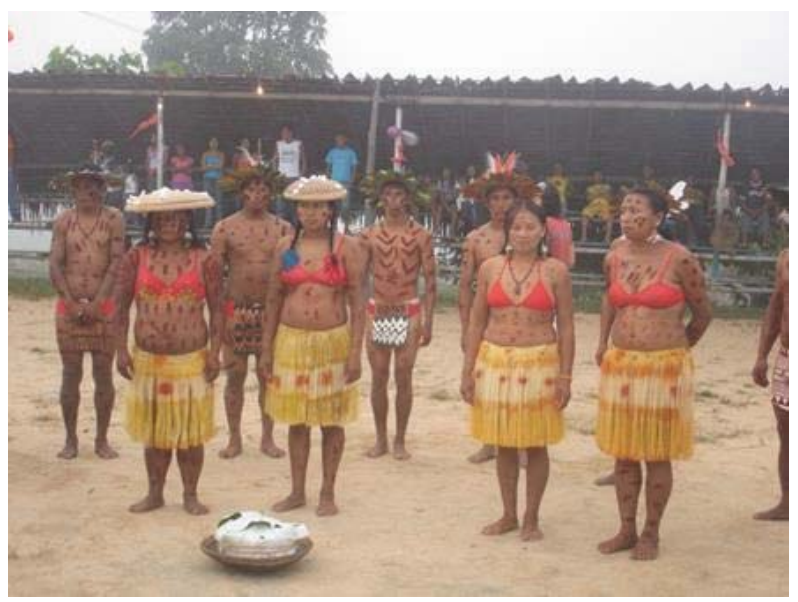

Picture 2. Baniwa Ethnic Group, Brazil.

Font: Blog do Ray Baniwa. Photo by Guilherme Gomes, UNESP Ciência.2011.

Different from other indigenous peoples of the Rio Negro river, the Baniwa don't practice linguistic exogamy and yes phratric exogamy although some partners who speak. They relate socially in practice the patrilineage and patrilocality are common. The region inhabited by the Baniwa presents low fertility soil and rivers of reduced availability of fishes. Marital relations are established, in order to ensure wide access to food resources, i.e. the members of certain phratries that have greater availability of farmland or that control lakes and igapó (flooded forest) (main sources of fish) has the preference of phratries opposed to the establishment of marriage agreement. This is one way the Baniwa to ensure their survival.

\section{Aspects of Culture Tikuna}

The Tikuna are an indigenous ethnic group that are distributed by three countries: Brazil, Colombia and Peru and represents one of the largest indigenous groups in the Brazil (GRUBER, 2004). With $90 \%$ of the total population is concentrated in Brazil, there are many in the State of Amazonas, distributing the region of Alto Solimões and representing an estimated population of 36,377 inhabitants (PALADINO, 2010). Geographically, are located in a wide territorial extension, which extends from the Loretuyaco river (current currency between Peru and Colombia) up to the mouth of the Iça river (Brazil), locating within the limits of the boundaries between Peru, Colombia and Brazil. In mythical context, are the rivers IçálPutumayo, Loretuyaco and the Solimões River which constitute the significant milestone of the definition of the Tikuna territory (ALBARRACÍN and CAYCEDO, 1999). Historically, the Tikuna moved to brazilian territory, in order to withdraw from the fight between Colombians and Peruvians by current Letícia territory. In brazilian territory, the Tikuna are concentrated in the municipalities of Tabatinga, Benjamin Constant, Amaturá, São Paulo Olivença and Santo Antonio do Içá, Jutaí, Fonte Boa, Tonantins and Beruri. Despite the political struggle of the processes of formation of national borders between the three countries, the historical events were important to consolidate the ethnic identity of the group don't generating among the Tikuna substantial divisions.

The social organization of internal tribe presents two groups strictly exogamies, matrimonial halves represented by Clan land (without feather) and Clan Air (with a feather). Being new patrilineal, running a priori the practice of mobility of the bride to the residence of the parents of the bridegroom, to the generation of the third son, when the couple has the right to live in their own residence. Something interesting that was observed in the study of CAYCEDO and ALBARRACÍN (1999) in the territory of Colombia, is that the Tikuna despite exogamic, they feature characteristics territorial endogamous. In other words, marital relations of halves are respected, but the weddings almost all happen in the same tribe, unfavorably the mobility of the bride between another tribes villages. In this way, the relationship is to be closed between the Tikuna, favoring the marriage between crossed cousins and the inbreeding (blood relation) in one and the same territory. 


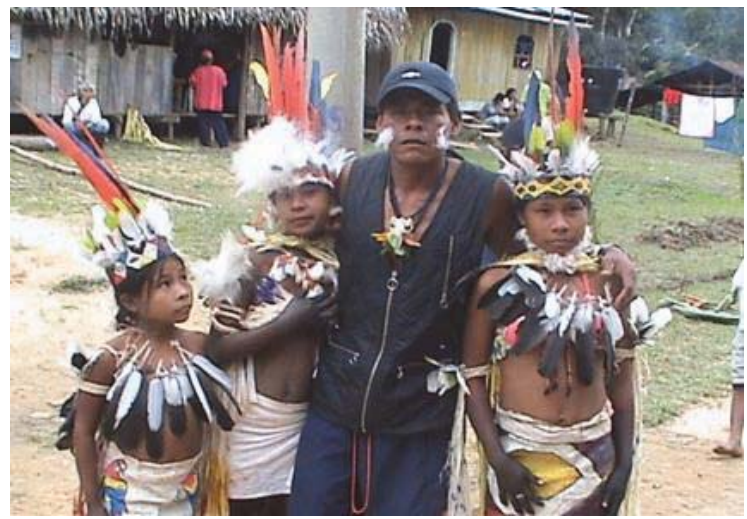

Picture 3. Tikuna Ethnic Group, Alto Rio Negro, State of Amazon, Brazil.

Font: Small World Foundation. 2009.

The establishment of social organization among the Tikuna is revealed by the format of malocas (indigenous benab). Due to the influence of western culture, many malocas are being replaced by houses, that is changing the figure head of maloca for the owner of the house. In a same maloca can coexist in one until three families, and low incidence of this configuration, since the Tikuna reproduce very fast.

The Tikuna always were considered good farmers. They domesticam until today the manioc, cassava and maize. Fishing with harpoons, hooks, traps and they don't know the tarrafa (SCHROEDER, 2013). Formerly, were considered experts in the preparation of curare, used at the tips of the arrows and javelin to immobilise the fishing and hunting. The curare is kind of a poison able to anesthetize the muscle of prey, immobilising it for a few seconds. Your preparation is the outpouring of plants, zest of rattan Güre and use of a tubercle abrasion with the langue of pirarucu (SCHROEDER, 2013 apud NIMUENDAJÚ, 1930). The bow and arrow are currently in disuse and were replaced by rifle, supplanting the old traps of hunting. The zarabatana (kinf of blowpipe) can be found rarely in the villages and the art for the preparation of curare became unknown to many.

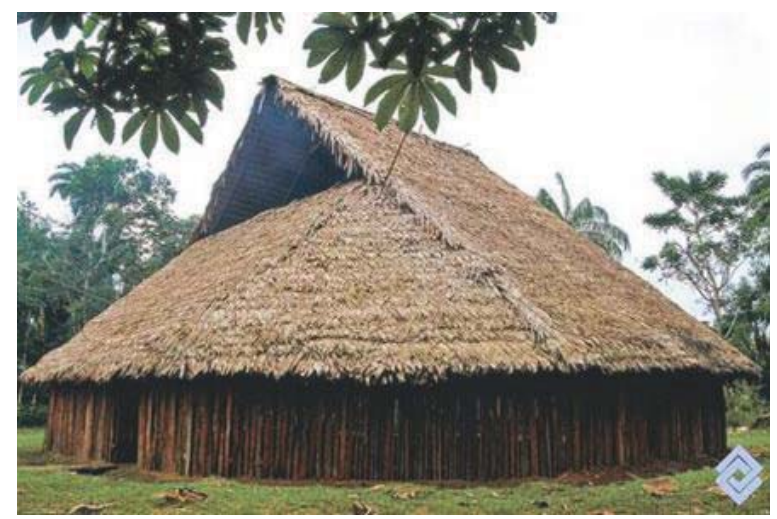

Picture 4. The Maloca, Amazonia. Colombia, 2009.

Font: Photo by Germán Montes Vieira, 2008. In. La Amazônia del Colombia. Banco de Ocidente.

The Tikuna women are considered to be good potters. Are responsible to do dishes, pots, pans, clay pot and roasters. An another ability very this is weaving. They produce baskets, bracelets and bags with twisted rattan. Handle very well the plant extracts of pigments, that soothing strokes, Thai stretches the products and give the desired color.

The Tukanos, differently of Tikuna create chickens for food and also the sell. The Tikuna adopted the use of the wooden spoon, the juicer of cane and the more curious, the "tipiti"). 
Despite common opinion, the "tipiti") was not used by Ticuna expressing preparing cassava with the preparation of flour, cassava bread and fermented beverage (SCHROEDER, 2013 apud NIMUENDAJÚ, 1930).

\section{Cosmology of the Baniwa}

The Baniwa cosmology is based on ancestral family formed by Niãpirikoli, his two brothers and his son Kowái. They are responsible for marriage rules, rites, definition of food plants and medicinal, in addition to the art of fishing. The mythological narratives define the social organization of the Baniwa and their relationship with nature and with the food. Different of Tikuna, the Baniwa believe in a cosmology nature/social in that so many animals as well as men, have spirit. It all starts with the formation of Içana river, abundant river in the territory inhabited by the Baniwa. This river was formed through the runoff caused by bird Keerao, after sorcery of shamanic god Niãpirikoli intended for the bird that had sexual relations with his wife. It was through chants and breath tube of tobacco that the world began to expand and life arose in Içana river. For example, the fish was produced from the breath of tobacco in wood tube. Some fish created by the breath of tobacco of Niãpirikoli grew in power and size, giving rise to large snakes; currently considered the fathers of fish. For the Baniwa, the fish and snakes are kin (Garnelo, 2007). Some narratives describe that there is a tension between Niãpirikoli and snakes (predators of humans) by area of lakes and rivers. Niãpirikoli manages to oust the snakes which in turn leads to capacity multiplier of fish in Içana river. After much smoke (breath of tobacco), the society-fish is able to restore again in rivers, although there is conflict between the men and the snakes.

\section{The Tikuna Cosmology}

The myth of Tikuna ancestral is based in the fight between the two brothers Dyoi and Ipi, the involvement of Ipi with the Dyoi's woman. The mythological story describes that Ipi became pregnant at his sister in law. Dyoi when discovered, he tried to make Ipi disappear in different ways. One of them was as soon as the Ipi's son was born. Dyoi asked for his brother Ipi grating fruits of Jenipapo in order to paint the child. Ipi grated a lot of Jenipapo and she could no longer stop because his brother Dyoi don't allowed, until it started to grate by himself, he grated the arms, legs and soon became intertwined mass of Jenipapo. Dyoi painted the boy with the mass of Jenipapo and the rest played in river. The mixture of Ipi with the jenipapo became nutrient for the proliferation of fish. This mass has come to achieve to the Amazon River until to the part of Amaturá, where live the Tikuna until today.

When Dyoi was fishing, he used several baits and with the cassava he managed to catch fish that turned into Tikuna persons. Then he tried fishing his brother and he couldn't do it. Then he called his wife and said to him: "see if you can fish your lover". Ipi as soon as he hook and returned to his old world. Dyoi asked him fishing his people. Ipi after many attempts, with manioc bait fished the Peruvians Tikuna. The descendants of Ipi went to live in the west and the Dyoi to the east. The mythology defines the territorial distribution between them today. The Ipi live on the peruvian side of Dyoi on the brazilian side. The Colombians Tikuna are also part of Ipi, as formerly the territory was occupied by Peruvians (Garces, 2000).

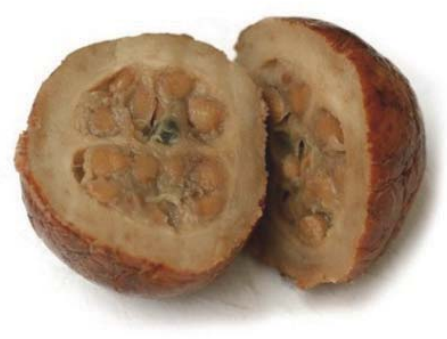

Picture 5. Jenipapo or Lambedor (Genipa Americana)

Font: LS Distribuidora de Alimentos LTDA, 2014. 


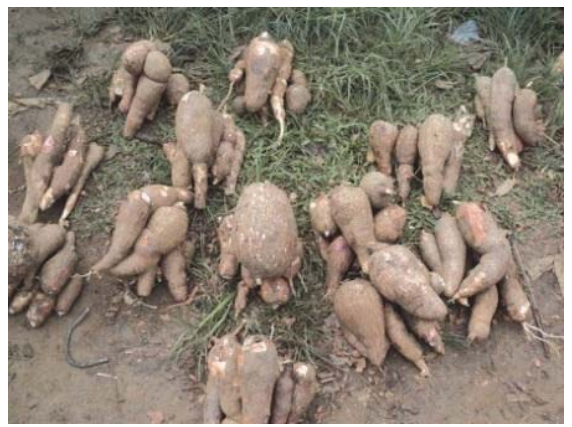

Picture 6. Manioc, Macaxeira or Cassava (Manihot Crantz esculenta).

Font: Motto Essome Kuntz Legrand et Martial Gervais Oden Bella, 2011.

It's worth mentioning that the Tikuna, from the mythology, represent one of the major protein food for indigenous peoples, who are fish. It is interesting to see what the fish presents to this ethnic group, because even being descendants of fish, notify the dependence of fish only as a food source. Doesn't exist for them on behalf of the companies man-animals, according with the perspectivism described by Viveiros de Castro (1996). Another interesting item is that Dyoi fishing with manioc and Ipi with the macaxeira the Tikuna. These two tubers are the main materials used for the preparation of the meal. They are mixed, and there is the need to eliminate the poison of cassava (hydrocyanic acid).

\section{The Food of the Baniwa}

An essential feature of the Baniwa way life is the establishment of correlations between cosmology and the production and consumption of food in the north-west of Amazon indigenous. Based on the studies of Christine Hugh-Jones (1979), the cosmos for the Baniwa enfolds humans and animals within the intersubjective field, even though each of the terms of this relationship assumes a symmetric perspective, but reversed, the seizure of another. This means that the Baniwa consider some animals (snakes, jaguar, alligator, others) as subject, predators of men, as well as humans, predators of animals. This relationship between predator and prey is established to maintain the balance of the Baniwa cosmos.

In Baniwa cosmology, Niãpirikoli believed that several times his father he wanted to kill, mainly, through the poisoned fish. To counteract the action of the venom, Niãpirikoli would have created the pepper. The poison to them means death and disease. Therefore, the pepper is used in cooking of fish to prevent the Baniwa of any disease. Another characteristic mythological that guides the habit of eating the food the Baniwa is the elimination of the pitiú (smell). They are believed that the smell may be a source of various diseases and the mythic, the tale refers to semen of the great snake expelled by Niãpirikoli.

The basis of the diet of the population Baniwa is seated in the agriculture of manioc (and cassava), on hunting and fishing. Due to the infertility of the soil that land place is the agriculture is little practiced.

Access to food and its preparation for the Baniwa are accompanied by an entire ritual and mythological beliefs. For example, the fisherman Baniwa to attract fish needs to deprive of sexual relations and food, to blessings performance and use plants of seduction. This ritual is necessary to highlight the power of attraction of the fisherman. For the preparation of food, one of the basic requirements is the cleaning of the female body. Women are responsible for preparing food and need to be bathed and scented for the preparation of food. If she's at the menstrual period shouldn't to make food by manipulation. The impurity is designated as attraction of negative spirits and aggressive that can contaminate food and cause indigestion. Another important ritual related to food is the blessing performances. The Baniwa believe that the fish as well as the snakes, depending on the size of the teeth and beaks, can bite, it has poisonous substances, sting, etc. Therefore, for the Baniwa there is a classification of fish related to the degree of danger. To eliminate the power of aggression, the fish is replaced by blessing performances, mainly, after certain events, such as: the post-birth, puberty and the recovery of a patient. GARNELO 2007 apud FAUSTO (2002) affirms that the blessing performances proposes to eliminate the condition concerning the subject of fish, transforming it into a pure object, i.e. only in pure food.

The commensality practiced among the Baniwa would be a form of "social etiquette of good manners", that has a deep meaning in the consolidation of alliances, the bonds of friendship and mutual respect. For example, the reception of 
a visitor implies in the provision of food, offered in accordance with the availability and the importance given to visitor. The sharing of food is given the power to please and plucked asunder the strangers. You can also represent an effective demonstration of confidence between the ancestors or an act of reaffirmation of the bond of friendship. The commensality among the Baniwa reaffirms the commitment to social attitudes and positive, away from any possibility of contamination and poisoning among the subjects. Those who refuse the food may be considered deviant and owners of poisons, they've being poorly seen in Baniwa society, may cause disruptions in the social origanization.

The practice of commensality is very common in rites of passage and the congregation of the Baniwa people in favor of the completion of any event. They usually prepare food to be shared in community hall, where the families are packed collective. In general, each family takes part of food prepared at home and contribute to the achievement of Community meal .

For the Baniwa the cold food and rehashed represents poison, being, therefore, rejected. The safest way to prepare it is boil or moquear (to dry by sun or fire) the food and when it comes to fish, cook with pepper (Garnelo, 2007). These beliefs reaffirm the possibility to eliminate the poison and remove the disease. If the subject is suspected of having a disease or is feeling not so well, begins a rigorous system of food discipline for elimination of the poison. The victims of snakebites also pass by the system of food discipline, with the participation of their kin. The union of relatives reaffirms ties and social bonds, reducing the possibility of the change from being an arm poison the victim into an animal. This passage in human-animal and animal-man is expressly accepts the Baniwa, which consider some animals as subjects.

In a study more recent in Baniwa territory were observed that certain foodstuffs are industrialized part of day-today food, serving also as items of exchange. Second CANEIRO et al (2008) the dry fish has served as an object of exchange by refined sugar, for example. Those who have some source of income use part of it for the purchase of industrialized food, generally in São Gabriel da Cachoeira city. This change is associated with the new sources of capitalization and ease of access to urban centers, by the availability of motor vehicles, There is a concern about how this change has affected the health of the Baniwa in relation to oral health, CANEIRO et al (2008) observed high incidence of missing teeth by bad poor hygiene, and is considered the largest in the entire Northern region. This worsening of oral health was also observed in other ethnic groups as Xavante and Kaiowá. were once Guarany Indians. The Xavante group, the incidence of bad oral conditions is attributed to the consumption of refined sugar and for the Farms Close the intake of several industrialized food (CANEIRO et al, 2008 apud Arantes et al. 2001).

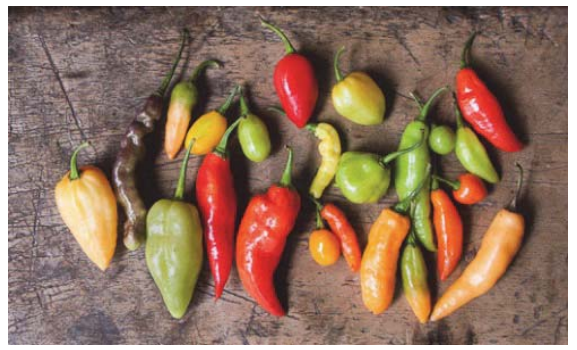

Picture 7A. Pimentas (peppers) utilized by Baniwa with word Jiquitaia or Pimenta Baniwa.

Font: Photo by Guilherme Gomes in A pimenta e a partilha. by Luciana Christante, 2010.

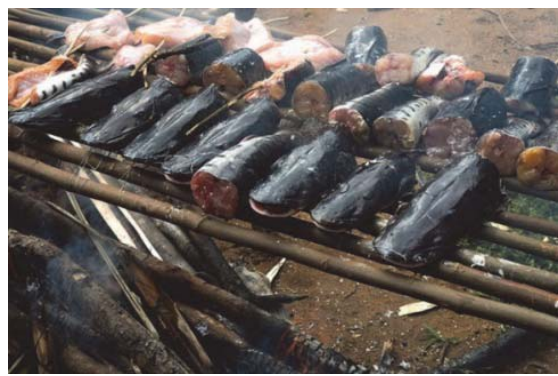

Picture 7B. Smoke Fish (dry fish) utilized by Baniwa.

Font: Photo by Edu Simões, The Guardian. Brazil's Star chef Alex Atala visits the Amazon - gallery. 2013. 
For the Baniwa, incidence of edentulism (exchange of natural teeth by artificial dentition) at a more advanced age is common, and, therefore, do not give much importance to the preservation of the teeth. The problem is the bad hygiene or not oral brush. The industrialized foods are potential sources for the production of tooth decay, due to the presence of sugars and other carbohydrates. In addition to the bad hygiene, was observed by CANEIRO et al (2008) that the dental loss may be due to the use of the teeth in cut and tailpiece of fibers during the cooking process basketry arumã.

\section{The Food of the Tikuna}

Different of the Baniwa, the Tikuna do not relate the food with the mythical world, but the uses in certain rituals and festive days, as for example, on the feast of the damsel new. The food has importance given to physical development and nutritional, whose food is fish, hunting, cassava and bananas. It is interesting to notice the importance of bananas, which is a usual very present in feed and Tikuna has perhaps suffered influence of Peruvians morals, who has the banana as a necessary food in almost all daily meals (PEÑA VENEGAS and BERNAL ZAMUDIO, 2011). According to reports in the literature, the banana was a product introduced in Tikuna Amazonian communities and gained space similar to the cassava. The banana is no longer common in power of the Baniwa, and may be a food of particular use of Tikuna. The rice is another food also very common among them. The introduction of rice and maize, as a component of food Tikuna diet occurred during the process of European colonization, being rice more appreciated by them.

Currently there is a marked tendency of Tikuna exchanging the healthy foods belonging to their culture by industrialized products. The ease of access to these products is due to its location. The majority live in communities very close to the urban centers and relate daily with the western culture. Therefore, it can be said that the Tikuna are more sociological than the inhabitants of Rio Negro.

In communities closer to urban centers, the main source of protein is no longer the fish and began to be the chicken, eggs, canned vegetable proteins. Already in most distant communities, the fish continues to be the main source of protein. Traditionally, in times of shortage of animal protein, the Tikuna wisdom comes into action and cassava leaves are consumed as the main source of vegetable protein. However, the source of protein animal is still the preferred and must accompany the food on the day. It is also possible that the diet is introduced other protein sources such as insects, rats and turtles.

There is a preference of Tikuna by liquid food, i.e. soups and broths. This was observed by Peña Venegas and Bernal Zamudio (2011) in a community of the Parana river, call of Huitoto, the Colombian side. The soups may be fish, pepper, cassava leaves, umari or mocambo. In communities closer to the urban centers is common the introduction of rice, there is a preference for the food net that drought. The Tikuna often feed twice a day, one in the morning before work and another at the end of the day. The meal is usually is cooked, fried or roasted prepared, being composed of a protein and a carbohydrate and a drink, and may take some time, depending on the availability, the intake of fruit, It is also common for the use of pepper and some spices such as: chicory, urucu and saffron.

The main source of carbohydrate for supply of Tikuna is the cassava. From this prepares the casabe (a kind of cake of cassava mass), flour, the tamal and the arepa. Unlike other ethnic groups, the Tikuna not wore the "tipiti") which is the main instrument used in the preparation of the mass of tapioca (Goma of cassava). This instrument was introduced in culture over time, therefore, is not very common for the preparation and consumption of tapioca by Tikuna, the most common being the preparation of it into cassava (Colombia) known as beiju in Brazil.

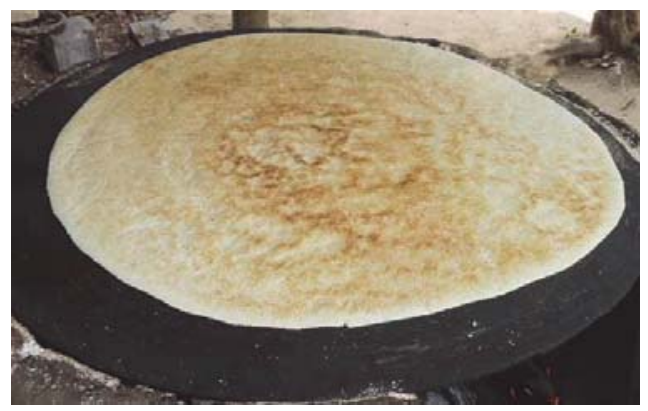

Picture 8A. Casabe, Cassava, Beiju or Tapioca.

Font: A falta de pan, Casabe! Photo by BCAMPDERA, 2013. 


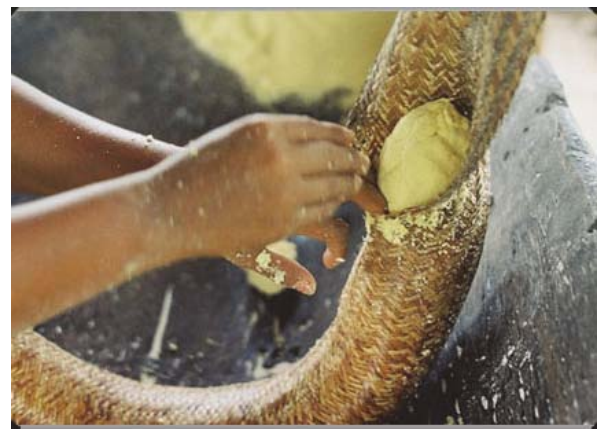

Picture 8B. Casabe, Cassava, Beiju or Tapioca.

Font: A falta de pan, Casabe! Photo by BCAMPDERA, 2013.

The technique used for the preparation of cassava is old and was introduced by the natives of the Amazon. The preparation of the meal, for example, shows that the indigenous people of the Amazon already knew the process of fermentation. The preparation of the meal involves the fermentation don't alcoholic, dehydration by press and by heat. In contrast, the arepa preparation consists in the mass of grated cassava, expressed and roast. This whole process of change physics and chemistry is part of indigenous knowledge and did not require scientific methods for their preparation and use.

Other acts present in daily meals of Tikuna are the different drinks. It is not common for the Tikuna drinking water after meal, they prefer drinks prepared. There are two types of drinks prepared by them: the fermented and not fermented. The drink does not fermented is specially prepared from the fruit of palm trees or the infusion of plants (teas).

The drinks of palms favorite of Ticuna are patauá juice, buriti, bacaba, buriti or açai. The preparation technique consists of placing the fruit soak in water basin and strike him to loosen the pulp. This was the most common way of juicing Açaí in large urban centers, before inventing the machines. The teas are consumed in smaller proportion, the most common being prepared from the leaves of guayusa (llex guayus) and bark of yoco (Paullinia yoco). It is important to highlight the wealth of nutritional drinks of palm trees, because it contains oils polyunsaturated fatty acids, protein, calcium, antioxidants, irons, etc, which are essential for diet of the indigenous peoples.

The fermented beverages more common are prepared earth of cassava and bananas, being the pupunha the less common. The preparation consists of leaving the material resting for 2 to 3 days in a basket up to exhale the characteristic odor that indicates the point of maturity, so the fruit or tuber is ready for juicing.

In addition to drinks commonly used in daily meals, the Ticuna prepare the wine of Payawarú especially to be served in special celebrations. Its preparation consists in using a special variety of manioc, which has a high content of sugars, which is grated, toasted and fermented until obtaining the wine to taste similar to red wine. The drink has pink whitish and a very sweet (Peña Venegas and Bernal Zamudio, 2011).

The technique of preparing drinks and food handling procedures involves very elaborate, a wealth of Tikuna that is being lost , as the foods of traditional practice are replaced by industrialized foods or supermarket products.

\section{Final Considerations}

In this context, we can understand that the wealth of knowledge of the indigenous peoples of the Amazon for the cultivation and preparation of food. The Baniwa develop their knowledge and food nutrition with strong relationship their mythological beliefs, while the Tikuna bring a legacy of its own knowledge of their ancestors, which stands out by use of techniques well developed (fishing, cultivation, preparation, etc) and by the process of fermentation.

The indigenous foods has a high nutritional value that the influence of western culture has been damaged, due to their replacement by industrialized products. As globalisation progresses, the indigenous knowledges are threatened in favor of a culture civilization, opening space for cultural erosion and to the devaluation of primitive practices on the world scene. Despite the devaluation, the indigenous contribution is present in much of the dishes and preparations served in the restaurants of the world, through the edible products and domesticated by them. In Amazonas, the fruit and the use of techniques of preparing regional are legacies left by the indians. The historical contribution is perceived through the preparation and consumption of flour and tapioca, the domestication of peach, pineapple, cupuassu, etc, by the 
consumption of drinks Açai, buriti, and bacaba, by strong habit of consumption of fish and lastly, in varieties of contributions that enrich the power of the population.

Historically, these knowledges cannot be reversed, even if they support the intolerance of western culture.

\section{References}

Albarracín, J.J.V. e Caycedo, A.O. (1999)La pesca entre los ticuna: historia, técnicas y ecosistemas. Boletín de Antropologia, v.13, n.30, p. 74-98.

Carneiro, M.C.G.; Santos, R.V.; Garnelo, L.; Rebello, M.A.B. \& Coimbra, C.E.A. (2008) Cárie dentária e necessidade de tratamento odontológico entre os índios Baniwa do Alto Rio Negro, Amazonas. Ciência e Saúde coletiva, v.13, n.6, p. 1985-1992.

Carneiro, M.C.G.; Santos, R.V.; Garnelo, L.; Rebello, M.A.B. \& Coimbra, C.E.A. (2001) Cárie dentária e necessidade de tratamento odontológico entre os índios Baniwa do Alto Rio Negro, Amazonas. Ciência\& Saúde coletiva, v.13, n.6, 2008, p. 1985-1992. In: Arantes R, Santos RV, Coimbra Jr. CEA. Saúde Bucal na população indígena Xavante de Pimentel Barbosa, Mato Grosso, Brasil. Cad. Saúde Pública, v. 17, 2001, p. 375-384.

Caycedo, A.O. e Albarracín, J.J.V. (1999) Mitades, clanes y casa del trapecio amazónico colombiano: una pespectiva numerica de los ticuna. Amazônia em Cadernos, Manaus, n.5, p. 39-67.

Garcés, C.L.L. (2000)Ticunas brasileros, colombianos y peruanos. Etnicidad y nacionalidad en la región de fronteras del alto Amazonas/Solimões. Doutorado em Antropología com ênfase em América Latina e o Caribe. Centro de Pesquisa e Pós Graduação Sobre América Latina e o Caribe, CEPPAC-UNB, Distrito Federal, Brasil. Editora Obtenção.

Garnelo, L. (2007) Cosmologia, ambiente e saúde: mitos e ritos alimentares Baniwa. Suplemento, v.14, p.191-212.

Garnelo, L. (2002) Cosmologia, ambiente e saúde: mitos e ritos alimentares Baniwa. Suplemento, v.14, 2007, p.191-212. In: FAUSTO, C. Banquete de gente: comensalidade e canibalismo na Amazônia. Mana, Rio de Janeiro, v.8, n.2, p.2-44.

Gruber, J.G.; Romanelli, L.I.; Barbosa, M.S. e Bendazzoli, S. (2004) Curso de ensino médio para as escolas ticunas do Alto Solimões. Organização Geral dos Professores Ticunas Bilíngües, Aldeia de Filadéfia, Benjamin Constant/AM, 36p.

Moreira, S.A. (2010) Alimentação e comensalidade: aspectos históricos e antropológicos. Ciência e Cultura, v.62, n.4, p. 23-26.

Paladino, M. (2010)Experimentando a Diferença- trajetórias de jovens indígenas Ticuna em escolas de Ensino Médio das cidades da região do Alto Solimões, Amazonas. Currículo sem fronteiras, v.10, n.1, p. 160-181.

Peña Venegas, C.P. e Bernal zamudio, H. (2011). Bases sócio-antropológicas del sistema de alimentación ticuna y huitoto. Zainak, 34, p.177-192.

Schröder, P. (2013)Primeira viagem aos Ticuna: um artigo pouco conhecido de Curt Nimuendajú. Bol. Mus. Para. Emílio Goeldi. Cienc. Hum., v. 8, n. 2, p. 461-470.

Schröder, P. (2013). Primeira viagem aos Ticuna: um artigo pouco conhecido de Curt Nimuendajú. Bol. Mus. Para. Emílio Goeldi. Cienc. Hum., v. 8, n. 2, 2013, p.461-470. In: NIMUENDAJÚ, C. Besuch bei den Tukuna-Indianern. Ethnologister Anzeiger, Stuttgart, v. 2, n.4, 1930, p. 188-194.

Viveros de Castro, E. (1996). Os pronomes cosmológicos e o perspectivismo ameríndio, Mana, Rio de Janeiro, v.2, n.2, p.115-144. 